\title{
Evolution of Calciocarbonatite Magma: Evidence from the Sövite and Alvikite Association in the Amba Dongar Complex, India
}

\author{
S. G. Viladkar \\ Carbonatite Research Centre, Amba Dongar, Kadipani, District Vadodara \\ India
}

\section{Introduction}

CaCO3-rich carbonatites seem to be the most common and abundant carbonatite in many complexes. The Amba Dongar complex too, is dominantly composed of sövite. Its dike equivalent-(alvikite I and II), though volumetrically less abundant, occur in association with sövite. Majority of sövites samples are composed essentially of $\mathrm{CaCO} 3$ and $\mathrm{MgO}$ content is low $(0.99 \%$ average) and goes up to maximum $3 \%$ in phlogopite-sövite. A small fraction of periclase was reported earlier from some sövite samples by Viladkar and Wimmenauer, [4]. In this paper I propose that sövites are crystallized from calciocarbonatite magma. Trace elements and REE distribution patterns suggest that sövite fractionated to Alvikite I and II. The $\mathrm{C}$ and $\mathrm{O}$ isotope data provides evidence to supports the mantle derivation of the carbonatite magma at Amba Dongar.

\section{General geology}

Amba Dongar carbonatite-alkalic rock diatreme is located on the western periphery of the Deccan flood basalt province in Gujarat State, Western India. This sub-volcanic diatreme consisting of different phases of carbonatites, nephelinites and phonolites, has intruded into the Bagh sandstone and overlying Deccan basalts sequence and has been dated at 65.5 Ma [1].

The outstanding geological feature of the Amba Dongar complex is the bold exposures and clear intrusive relationship between different carbonatite units. Sövite is the predominant type of carbonatite and forms a ring dike around the inner rim of carbonatite breccia (Fig.1). Apart from major ring dike, sövite also forms large and small plugs within the Bagh sandstone terrain. Ankeritic carbonatite intrudes sövite at several places as dikes and large oval plugs while, last in the differentiation sequence, sideritic carbonatite phase intrudes the ankeritic carbonatite as thin dikes, in the southwestern part of the ring structure. Alvikite (phase I), dikes equivalents of sövite, are widespread within as well as outside the ring structure. Alvikite phase II intrude sövite at some places along the ring dike. Nephelinite plugs and phonolite dikes occur in the outer periphery of the ring structure. Large reserves of hydrothermal fluorite deposits (11.5 million tones) are associated with the carbonatites. A 
vertical zonation of fenitization developed with strongly sodic and sodi-potassic fenites at deeper levels and potassic fenites at higher levels [2] [3]. The central part of the ring structure is occupied by intrusive basalt which replaced the original plug of carbonatite breccia. This youngest intrusive event seems to have occurred at $41.7 \mathrm{Ma}$ [3].

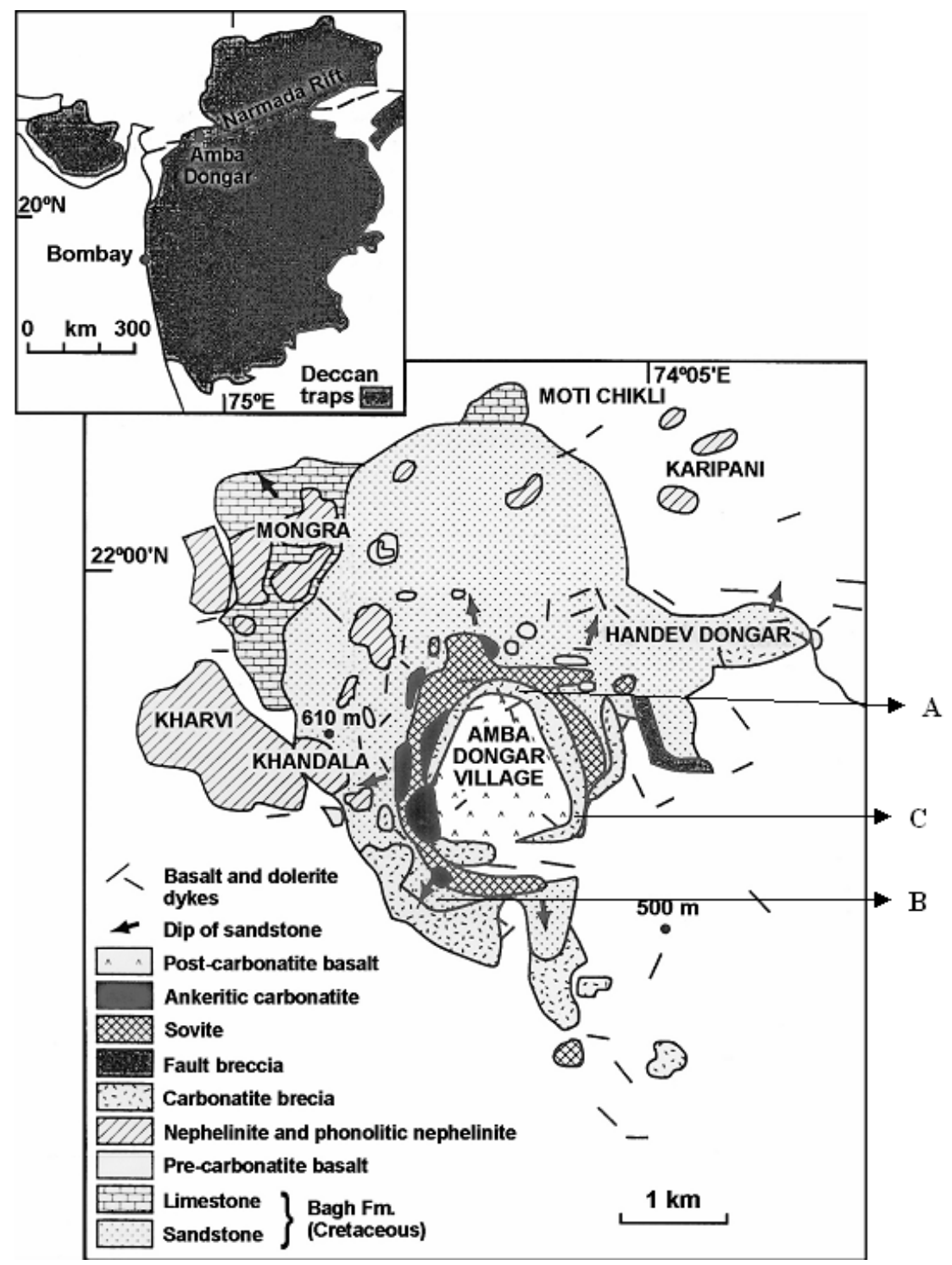

Fig. 1. Geological map of the Amba Dongar carbonatite diatreme with locations of Alvikite centres within sövite ring and outside the ring. A and C are in carbonatite breccia, B in Bagh sandstone. 
Evolution of Calciocarbonatite Magma:

It has been possible to establish the different phases of sövite intrusion with each phase marked by characteristic texture and mineralogy [3] [4]. The texture of sövite varies from coarse grained in the inner part of the ring in contact with carbonatite breccias to very fine grained in the outermost part of the ring in contact with the sandstone. Sövite also reveals excellent flow structure, and at several places large blocks of fenites are caught up within the flowage structure.

Early crystallization (segregations) of magnetite, apatite, pyrochlore and $\mathrm{Nb}$-zirconolite occur as bands within sövite (Fig. 2). Silico-sövites (phlogopite-sövite and pyroxene-sövite) are not exposed at present level of erosion, however; many xenoliths of these rocks were encountered at deeper levels during mining operations and also in a tunnel driven through the sövite exposure.

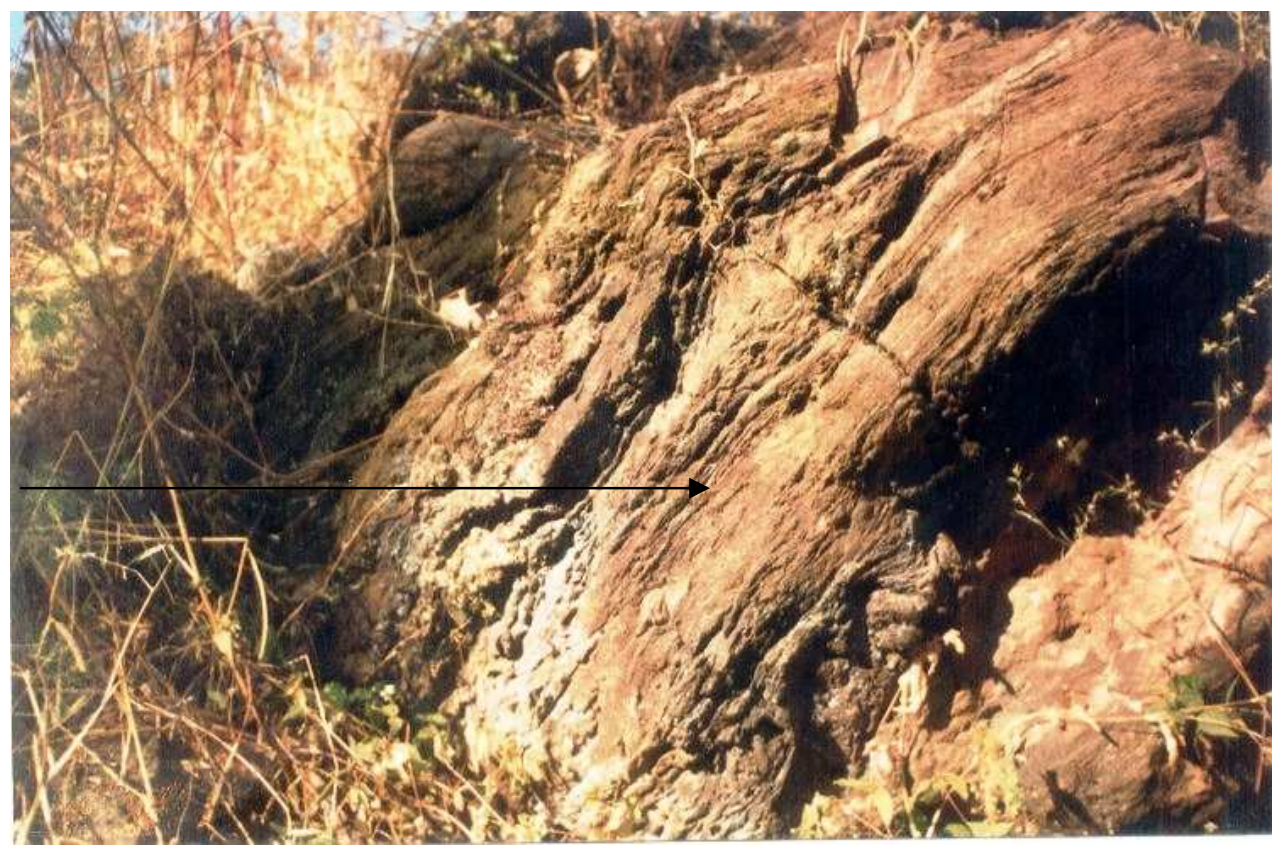

Fig. 2. Banding (shown by an arrow) in sövite.

The alvikites vary in thickness from several centimeters to almost a meter. Detailed field investigation of numerous dikes suggests that there are at least two distinct intrusive phases; one either predating or contemporaneous with the main phase of sövite intrusion while the second (alvikite II) clearly postdates the sövite intrusion. In general, alvikites do not show any particular trend in their disposition and, they are located all over the central ring structure as well as outside the ring structure in sandstones and basalts. Three main centres of alvikite (Fig. 1) have been located in and around the ring dike of sövite. Alvikites of phase I intrude mainly carbonatite breccia (Fig. 3), sandstone and basalts while those of the second phase intrude sövite and fenite outcrops. Apart from these exposures alvikites were also exposed in fluorite mine workings and along road cuttings. 


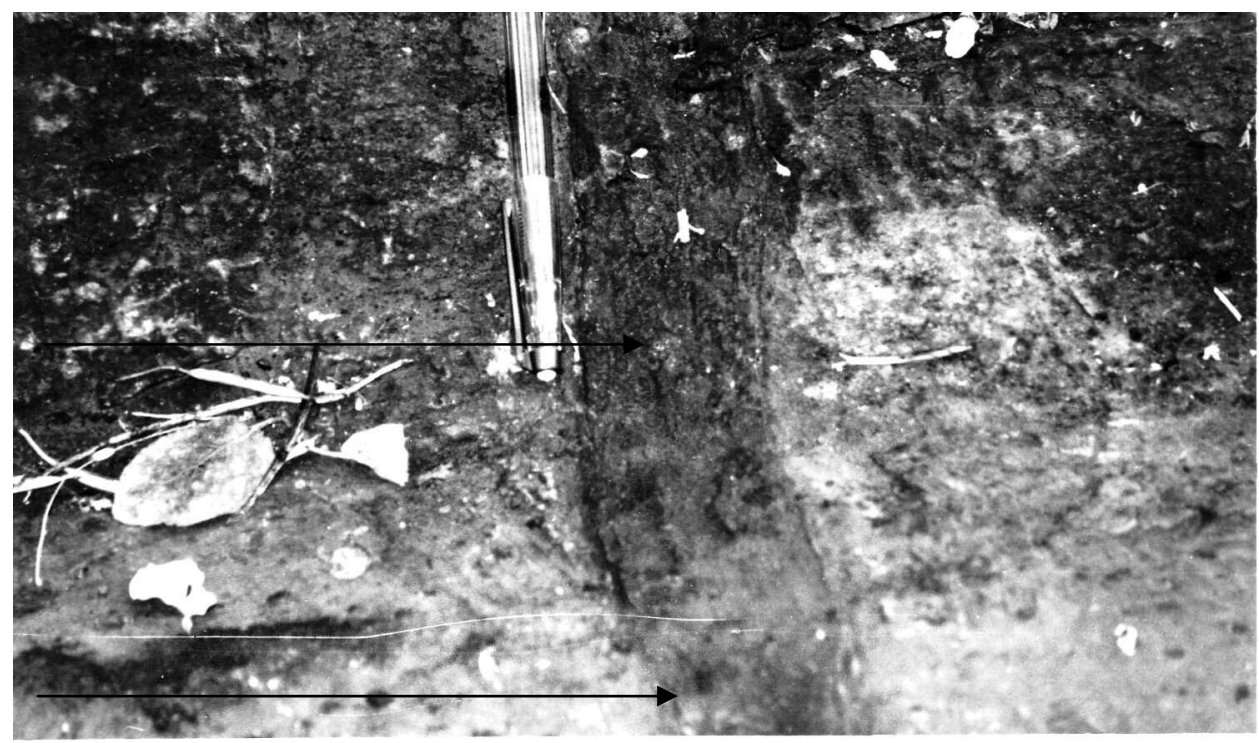

Fig. 3. Alvikite I (shown by an arrow) in carbonatite breccia.

The majority of phase I alvikites show thin chilled contacts with the host rocks. In some dikes grain size variation from margin (smaller grains) to center (larger grains) is observed. However, the most conspicuous feature observed around alvikite dikes of this phase (whenever they intrude sandstone) is the feldspathization of country rock sandstone. The fenitization effects along alvikite-basalt contact are not so conspicuous except for a small increase in $\mathrm{K}$ (formation of K-feldspar), modal apatite and calcite in the host basalt.

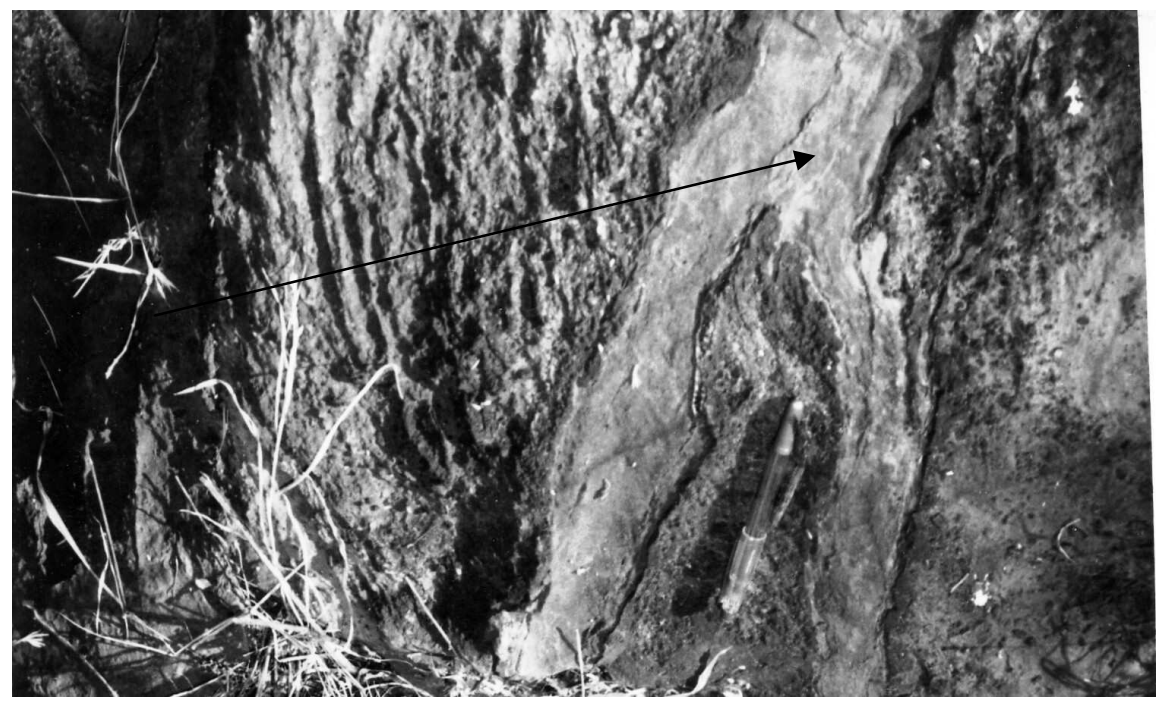

Fig. 4. Alvikite II (shown by an arrow) in sövite. 
Evolution of Calciocarbonatite Magma:

Evidence from the Sövite and Alvikite Association in the Amba Dongar Complex, India

Second generation alvikites (phase II) intrude sövite (Fig. 4) in the ring dike and some are located in exposures of fenites. Mineral zonation is clearly developed in some of these alvikites with margins exclusively rich in calcite while concentration of magnetite and pyrochlore in the central part of the dikes.

In Amba Dongar, along with intrusive phase of calciocarbonatite, the extrusive phase also occurs in the form of tuff (Fig.5) in the western part at Mongra [20].

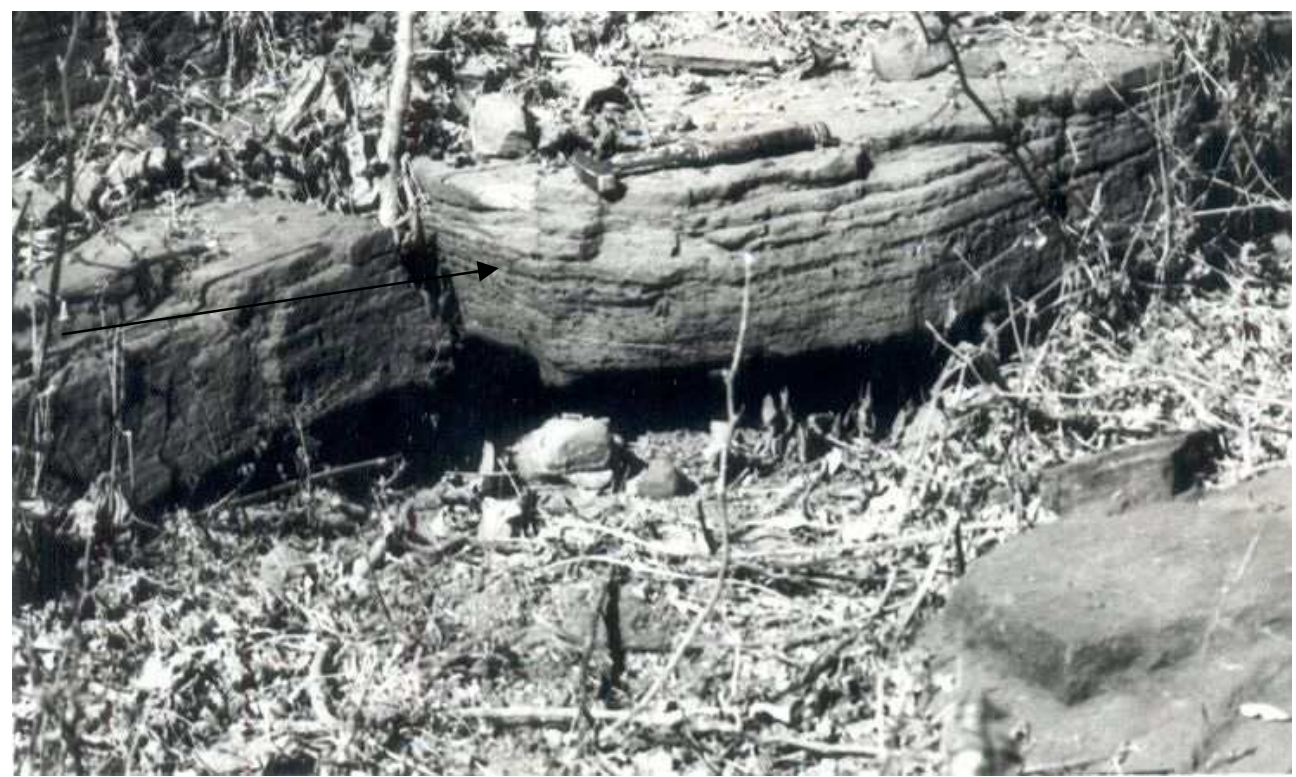

Fig. 5. Carbonatite tuff beds (shown by an arrow) in Mongra, West of Amba Dongar.

\section{Petrography and mineralogy}

Sövite shows various textures such as coarse grained, medium grained and, fine grained porphyritic [6]. In porphyritic types, the euherdal calcite phenocrysts are embedded in fine grained groundmass calcite of a later generation. In silico-sövites primary phlogopite is the most abundant silicate mineral while diopsidic augite is next in abundance. Phlogopite occurs as euherdal to sub-hedral crystals which locally show resorption by surrounding calcite. Occasionally phlogopite forms thin bands with individual crystals showing parallel orientation. The majority of phlogopite crystals are homogenous and do not show any zoning. Accessory minerals in order of decreasing abundance are apatite, magnetite, fluorite, barite, galena, pyrochlore, niobian-zirconolite, zircon, bastnaesite and monazite.

Alvikites, on the other hand, are medium to fine grained equigranular with anhedral grains of calcite and ankeritic calcite (in alvikite II) showing interlocking texture. Porphyritic texture is not uncommon. Some dikes show good flow texture with platy calcite crystals aligned along the direction of flow. All alvikite dikes of phase I have mineralogy broadly similar to coarse sövites whereas the post-sövite alvikites (phase II) are characterized by 
abundance of phlogopitic-biotite displaying strong zoning with pale brown core and dark brown rims. Oscillatory zoning is not uncommon. Dark brown to reddish brown tetraferriphlogopite occurs as small isolated flakes as well as rims of some strongly zoned crystals [7]. Octahedral magnetite is very common; sometimes it also forms a thin rim around pyrochlore.

Micas from sövites and alvikites were investigated in detail earlier and the details of their evolutionary history from sövite to alvikite are discussed in earlier publication [7]. The chemical differences shown by the two types of micas (Mg-rich in sövite and Fe-rich in alvikite II) and their evolution trends from sövite to Alvikite II are thought to reflect the chemical evolution of the calciocarbonatite magma from which they crystallized.

\section{Analytical method}

Major and trace elements were determined by X-ray fluorescence using a Philips PW 1450/20 instrument at the Mineralogische-Petrographisches Institute of the Albert-Ludwigs University, Freiburg im Br. Germany. Rare earth elements were determined by the Neutron Activation method at the B.A.R.C., Trombay, Mumbai (Note: where only Ce, La and $\mathrm{Nd}$ values mentioned in the analytical tables, these are the XRF analyses. Other REE analyses (La-Lu) are by the Neutron Activation method).

$\mathrm{C}$ and $\mathrm{O}$ isotopes were determined at the Biogeochemistry section of the Max-Planck Institute, Mainz, Germany using following method

Finely powdered (200 mesh-size) carbonatite samples were reacted for 72 hours with anhydrous (100\%) phosphoric acid at $25^{\circ} \mathrm{C}$ [8] [9] to ensure quantitative reaction of dolomite and ankerite components. Carbon and oxygen isotope ratios were determined for $\mathrm{CO}_{2}$ on a VG PRISM mass spectrometer equipped with a three-collector system allowing the simultaneous collection of the masses 44,45 , and 46 . Results were corrected for ${ }^{17} \mathrm{O}$ after Craig [9] and are reported as $\delta^{13} \mathrm{C}$ and $\delta^{18} \mathrm{O}$ values relative to the Pee Dee Belemnite (PDB) and Standard Mean Ocean Water (SMOW) standards, respectively, with

$$
\delta^{13} \mathrm{C}=\left\{\left[\left({ }^{13} \mathrm{C} /{ }^{12} \mathrm{C}\right) \mathrm{sa} /\left({ }^{13} \mathrm{C} /{ }^{12} \mathrm{C}\right) \mathrm{st}\right]-1\right\}{ }^{*} 1000(\% \text { o })
$$

and

$$
\delta^{18} \mathrm{O}=\left\{\left[\left({ }^{18} \mathrm{O} /{ }^{16} \mathrm{O}\right) \mathrm{sa} /\left({ }^{18} \mathrm{O} /{ }^{16} \mathrm{O}\right) \mathrm{st}\right]-1\right\}{ }^{*} 1000(\% \text { o })
$$

were sa $=$ sample and st $=$ standard. Standard deviations of the measurements were usually smaller than $\pm 0.1 \%$.

\section{Geochemistry}

The present section is aimed mainly to show how the parent calciocarbonatite magma at Amba Dongar fractionated. Geochemical differences between sövite and alvikite (phases I and II) during their evolution are brought out using spidergam for trace elements and the chondrite normalized REE patterns. Representative major, trace and rare earth elements anlyses of sövite, alvikite (phase I) and alvikite (phase II) are given in tables 1, 2 and 3 respectively. 
Sample 1201SOV 1244SOV 1250SOV 1270SOV 187SOV 195SOV Ave. SD CV\%

\begin{tabular}{|c|c|c|c|c|c|c|c|c|c|}
\hline $\mathrm{SiO} 2$ & 2.33 & 7.19 & 0.68 & 3.82 & 4.82 & 2.62 & 2.97 & 3.167 & 0.949 \\
\hline $\mathrm{TiO} 2$ & 0.96 & 0.15 & 0 & 0 & 0.41 & 0 & 0.09 & 0.182 & 1.889 \\
\hline $\mathrm{Al} 2 \mathrm{O} 3$ & 0.26 & 0.18 & 0 & 0.17 & 0.58 & 0.18 & 0.16 & 0.187 & 1.232 \\
\hline $\mathrm{Fe} 2 \mathrm{O} 3$ & 2.22 & 2.08 & 1.66 & 1.1 & 5.25 & 1.74 & 2.63 & 2.468 & 0.955 \\
\hline $\mathrm{MnO}$ & 0.59 & 0.53 & 0.73 & 0.44 & 0.15 & 0.66 & 0.5 & 0.429 & 0.826 \\
\hline $\mathrm{MgO}$ & 0.26 & 0.16 & 3.08 & 0.16 & 2.05 & 1.16 & 0.99 & 0.972 & 1.067 \\
\hline $\mathrm{CaO}$ & 50 & 47.84 & 50.57 & 51.9 & 47.19 & 50 & 49.34 & 3.511 & 0.071 \\
\hline $\mathrm{Na} 2 \mathrm{O}$ & 0 & 0.15 & 0 & 0.12 & 0 & 0 & 0.04 & 0.066 & 1.516 \\
\hline $\mathrm{K} 2 \mathrm{O}$ & 0 & 0 & 0 & 0 & 0.16 & 0 & 0.06 & 0.066 & 1.232 \\
\hline P2O5 & 0.6 & 3.47 & 0.45 & 1.04 & 3.99 & 0.19 & 1.69 & 1.469 & 0.855 \\
\hline $\mathrm{CO} 2$ & 41.89 & 36.3 & 41.52 & 40.2 & 33.32 & 41.74 & 39.76 & 2.814 & 0.071 \\
\hline Total & 99.31 & 98.05 & 98.69 & 98.95 & 97.92 & 98.29 & 92.95 & & \\
\hline $\mathrm{Ba}$ & 770 & 3860 & 6580 & 920 & 980 & 4130 & 4080 & 3125 & 0.786 \\
\hline $\mathrm{Sr}$ & 6100 & 3630 & 2560 & 5515 & 6310 & 2260 & 6871 & 6402 & 1.018 \\
\hline $\mathrm{Nb}$ & 1070 & 250 & 190 & 110 & 80 & 490 & 535.88 & 1179 & 0.636 \\
\hline $\mathrm{Zr}$ & 80 & 110 & 70 & 35 & 260 & 80 & 101.51 & 151.58 & 2.204 \\
\hline$Y$ & 50 & 230 & 60 & 130 & 80 & 110 & 124 & 77.64 & 1.427 \\
\hline Th & 120 & 130 & 60 & 30 & 80 & 40 & 59 & 56.64 & 0.796 \\
\hline $\mathrm{U}$ & 10 & 45 & 0 & 50 & 30 & 0 & 13.97 & 30.12 & 1.988 \\
\hline V & 10 & 0 & 65 & & 115 & 50 & 110.14 & 157 & 1.483 \\
\hline $\mathrm{La}$ & 290 & 1110 & 662 & 1830 & 666 & 1080 & 1040.44 & 894.4 & 0.903 \\
\hline $\mathrm{Ce}$ & 879 & 2460 & 1660 & 2980 & 1350 & 2800 & 2581.14 & 2697 & 1.117 \\
\hline $\mathrm{Nd}$ & 233 & 550 & 375 & 410 & 446 & 695 & 572.05 & 459 & 0.862 \\
\hline $\mathrm{Sm}$ & 34 & 125 & 47 & 44 & 58 & 177 & & & \\
\hline $\mathrm{Eu}$ & 9.23 & 19.9 & 11.3 & 10.4 & 14.3 & 25.3 & & & \\
\hline $\mathrm{Tb}$ & 3.09 & 8.61 & 3.59 & 4.32 & 4.15 & 7.95 & & & \\
\hline $\mathrm{Yb}$ & 4.28 & 16 & 3.5 & 12.7 & 4.2 & 8.83 & & & \\
\hline $\mathrm{Lu}$ & 0.55 & 2.33 & 0.4 & 1.78 & 0.55 & 0.87 & & & \\
\hline
\end{tabular}

Table 1. Representative analyses of sövite from different parts of ring dike and plugs. 


\begin{tabular}{|c|c|c|c|c|c|c|c|}
\hline & 1 & 2 & 3 & 4 & 5 & 6 & \\
\hline Sample & $1272 \mathrm{AD}(\mathrm{I})$ & 1292AD(I) & 79AD(I) & $86 / \mathrm{A} / 48(\mathrm{I})$ & $\begin{array}{r}\mathrm{BH} / 15 \\
/ \mathrm{ALV}\end{array}$ & $\begin{array}{r}\mathrm{V} / \mathrm{alk} / \\
68\end{array}$ & Ave \\
\hline $\mathrm{SiO} 2$ & 1.64 & 2.48 & 1.44 & 3.78 & 1.56 & 6.22 & 3.65 \\
\hline $\mathrm{TiO} 2$ & 0.00 & 0.00 & 0.11 & 0.02 & 0.11 & 0.13 & 0.09 \\
\hline $\mathrm{A} 12 \mathrm{O} 3$ & 0.37 & 0.00 & 0.11 & 0.21 & 0.07 & 1.78 & 0.75 \\
\hline $\mathrm{Fe} 2 \mathrm{O} 3$ & 1.20 & 0.40 & 2.11 & 1.03 & 3.19 & 1.29 & 1.84 \\
\hline $\mathrm{MnO}$ & 0.44 & 0.20 & 0.85 & 0.28 & 0.16 & 0.37 & 0.28 \\
\hline $\mathrm{MgO}$ & 0.17 & 0.80 & 0.24 & 0.60 & 0.42 & 1.46 & 0.75 \\
\hline $\mathrm{CaO}$ & 51.68 & 53.26 & 50.10 & 51.65 & 50.49 & 48.52 & 49.42 \\
\hline $\mathrm{Na} 2 \mathrm{O}$ & 0.20 & 0.10 & 0.18 & 0.06 & 0.05 & 0.54 & 0.16 \\
\hline $\mathrm{K} 2 \mathrm{O}$ & 0.00 & 0.00 & 0.00 & 0.10 & 0.00 & 0.59 & 0.37 \\
\hline $\mathrm{P} 2 \mathrm{O} 5$ & 0.30 & 0.00 & 0.47 & 0.15 & 3.24 & 0.09 & 0.87 \\
\hline $\mathrm{CO} 2$ & 42.04 & 42.10 & 40.78 & 41.50 & 39.80 & 38.90 & 40.48 \\
\hline Total & 98.54 & 97.34 & 96.39 & 99.38 & 100.49 & 99.91 & \\
\hline $\mathrm{Ba}$ & 2815.00 & * & 9850.00 & 211.00 & 485.00 & 210.00 & 2960.3 \\
\hline $\mathrm{Sr}$ & 16410.00 & * & 5210.00 & 2407.00 & 4295.00 & 1282.00 & 6610 \\
\hline $\mathrm{Nb}$ & 40.00 & * & 160.00 & 70.00 & 135.00 & 10.00 & 87.9 \\
\hline $\mathrm{Zr}$ & 20.00 & * & 80.00 & 44.00 & 220.00 & 78.00 & 161.5 \\
\hline $\mathrm{Y}$ & 175.00 & * & 155.00 & 70.00 & 40.00 & 33.00 & 226.8 \\
\hline Th & 120.00 & * & 130.00 & 10.00 & 40.00 & 0.00 & 59.4 \\
\hline $\mathrm{U}$ & 20.00 & * & 20.00 & 0.00 & 10.00 & 0.00 & 62.44 \\
\hline $\mathrm{V}$ & * & * & * & 33.00 & 85.00 & 40.00 & 23.3 \\
\hline $\mathrm{La}$ & 1070.00 & 354.00 & 1830.00 & 823.00 & 310.00 & 60.00 & 634.18 \\
\hline $\mathrm{Ce}$ & 2140.00 & 680.00 & 3340.00 & 1430.00 & 690.00 & 120.00 & 1237.455 \\
\hline $\mathrm{Nd}$ & 445.00 & 181.00 & 612.00 & 230.00 & 200.00 & 45.00 & 265 \\
\hline $\mathrm{Sm}$ & * & 30.00 & 73.00 & 64.00 & * & 14.00 & \\
\hline $\mathrm{Eu}$ & 16.30 & 7.51 & 16.20 & 7.93 & * & 4.00 & \\
\hline $\mathrm{Tb}$ & 6.57 & 2.93 & 6.65 & 2.10 & * & 2.00 & \\
\hline $\mathrm{Yb}$ & 11.80 & 6.37 & 8.60 & 1.70 & * & 1.50 & \\
\hline $\mathrm{Lu}$ & 1.41 & 0.79 & 1.22 & 0.34 & * & 2.00 & \\
\hline
\end{tabular}

Table 2. Representative analyses of alvikite I. 


\begin{tabular}{|c|c|c|c|c|c|}
\hline & 1 & 2 & 3 & 4 & \\
\hline Sample & 1246/AD/II & 1268(II) & 1269AD(II)* & 1288(II) & Ave \\
\hline $\mathrm{SiO} 2$ & 8 & 4.77 & 5.19 & 1 & 4.11 \\
\hline $\mathrm{TiO} 2$ & 0.1 & 0.15 & 0.12 & 0.23 & 0.17 \\
\hline $\mathrm{Al} 2 \mathrm{O} 3$ & 0 & 0.05 & 0.04 & 0.04 & 0.07 \\
\hline $\mathrm{Fe} 2 \mathrm{O} 3$ & 8 & 10.21 & 7.9 & 9.3 & 8.19 \\
\hline $\mathrm{MnO}$ & 1.5 & 0.74 & 1.43 & 0.5 & 0.84 \\
\hline $\mathrm{MgO}$ & 0.6 & 0.41 & 0.45 & 0.8 & 0.5 \\
\hline $\mathrm{CaO}$ & 45 & 40.2 & 44.48 & 46.3 & 45.08 \\
\hline $\mathrm{Na} 2 \mathrm{O}$ & 0.1 & 0.12 & 0.15 & 0 & 0.07 \\
\hline $\mathrm{K} 2 \mathrm{O}$ & 0.2 & 0 & 0 & 0 & 0.03 \\
\hline P2O5 & 2.1 & 1.12 & 0.49 & 1.6 & 1.01 \\
\hline $\mathrm{CO} 2$ & 37.6 & 40.5 & 38.2 & 39 & 38.43 \\
\hline Total & 100.2 & 98.27 & 98.45 & 98.77 & 98.26 \\
\hline $\mathrm{Ba}$ & 12800 & 10810 & 8730 & 8200 & 8438 \\
\hline $\mathrm{Sr}$ & 17510 & 3910 & 3210 & 6570 & 6059 \\
\hline $\mathrm{Nb}$ & 1600 & 1890 & 580 & 1670 & 956 \\
\hline $\mathrm{Zr}$ & * & 140 & 80 & 200 & 91 \\
\hline Y & 180 & 120 & 130 & 80 & 112 \\
\hline Th & 40 & 50 & 20 & 110 & 99 \\
\hline $\mathrm{U}$ & * & 25 & 40 & 5 & 13 \\
\hline V & 1055 & 200 & 135 & 0 & 269 \\
\hline $\mathrm{La}$ & 2070 & 2140 & 2360 & 770 & 1508 \\
\hline $\mathrm{Ce}$ & 8370 & 6010 & 5870 & 2250 & 4051 \\
\hline $\mathrm{Nd}$ & 935 & 1050 & 1310 & 460 & 826 \\
\hline Sm & * & * & 216 & * & \\
\hline $\mathrm{Eu}$ & * & * & 34.6 & * & \\
\hline $\mathrm{Tb}$ & * & * & 9.4 & * & \\
\hline $\mathrm{Yb}$ & * & * & 3.5 & * & \\
\hline $\mathrm{Lu}$ & * & * & 0.83 & * & \\
\hline
\end{tabular}

Table 3. Representative analyses of Alvikite II.

On the $\mathrm{CaO}-\mathrm{MgO}-\mathrm{Fe}^{\mathrm{t}}+\mathrm{MnO}$ plot (Fig 6) there is clear separation between sövite and alvikite II (alvikite I plot in the same field as sövites). The alvikite II are richer in Fe on account of presence of ankeritic calcite in them. Most sövites and alvikites in Amba Dongar show $\mathrm{MgO}$ content below 1 wt \% while those with $\mathrm{MgO}$ more than $1 \mathrm{wt} \%$ have either phlogopitic mica or periclase in them. Higher $\mathrm{Fe}_{2} \mathrm{O}_{3}$ contents of one sövite is due to high modal magnetite in this rock while the high $\mathrm{Fe}_{2} \mathrm{O}_{3}$ content of phase II alvikites can be attributed to a small amount of oxidized ankeritic calcite present in them.

The fractionation from sövite to alvikites (I and II) can be brought out more clearly on the spidergram for trace elements and chondrite normalized REE patterns. Plotting of average values of trace elements in sövites, alvikite (I) and (II) (Fig.7) show that incompatible trace elements gradually increase from alvikite I $\rightarrow$ sövite $\rightarrow$ alvikite (II), and as compared to alvikite I and sövites, alvikite II is enriched in all trace elements except $\mathrm{Sr}$, Zr and Y. 


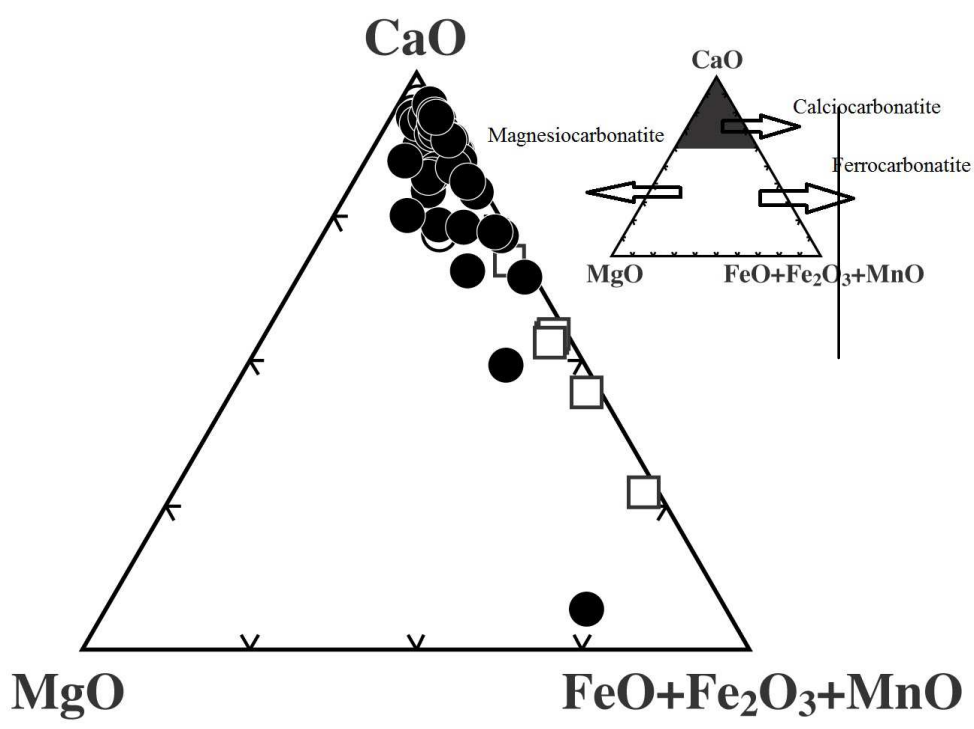

Fig. 6. Amba Dongar sövites (filled circles), Alvikite I (open circles) and Alvikite II (open squares) plotted on $\mathrm{CaO}-\mathrm{MgO}-\mathrm{FeO}+\mathrm{Fe}_{2} \mathrm{O}_{3}+\mathrm{MnO}$.

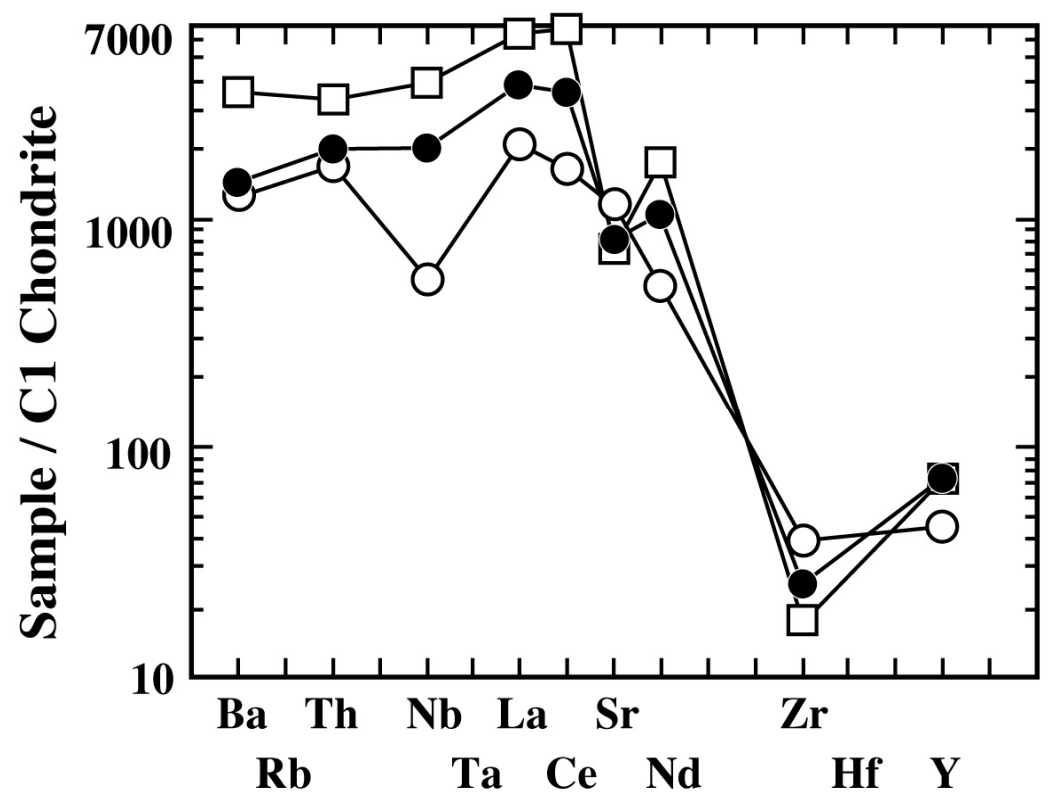

Fig. 7. Spidergram showing trace element variation in averages of Amba Dongar Alvikite I (open circle), Alvikite II (open square) and sövites (filled circle). 
Chondrite normalized plots of sövite (two different phases, coarse and fine grained) and alvikites (I and II) of Amba Dongar are shown in Fig. 8. Alvikite II is strongly enriched in all REE in comparison to Alvikite I and sövites. Steep slope of LREE/HREE, similar and parallel REE patterns point to fractionation during evolution of these two types of carbonatites in Amba Dongar.

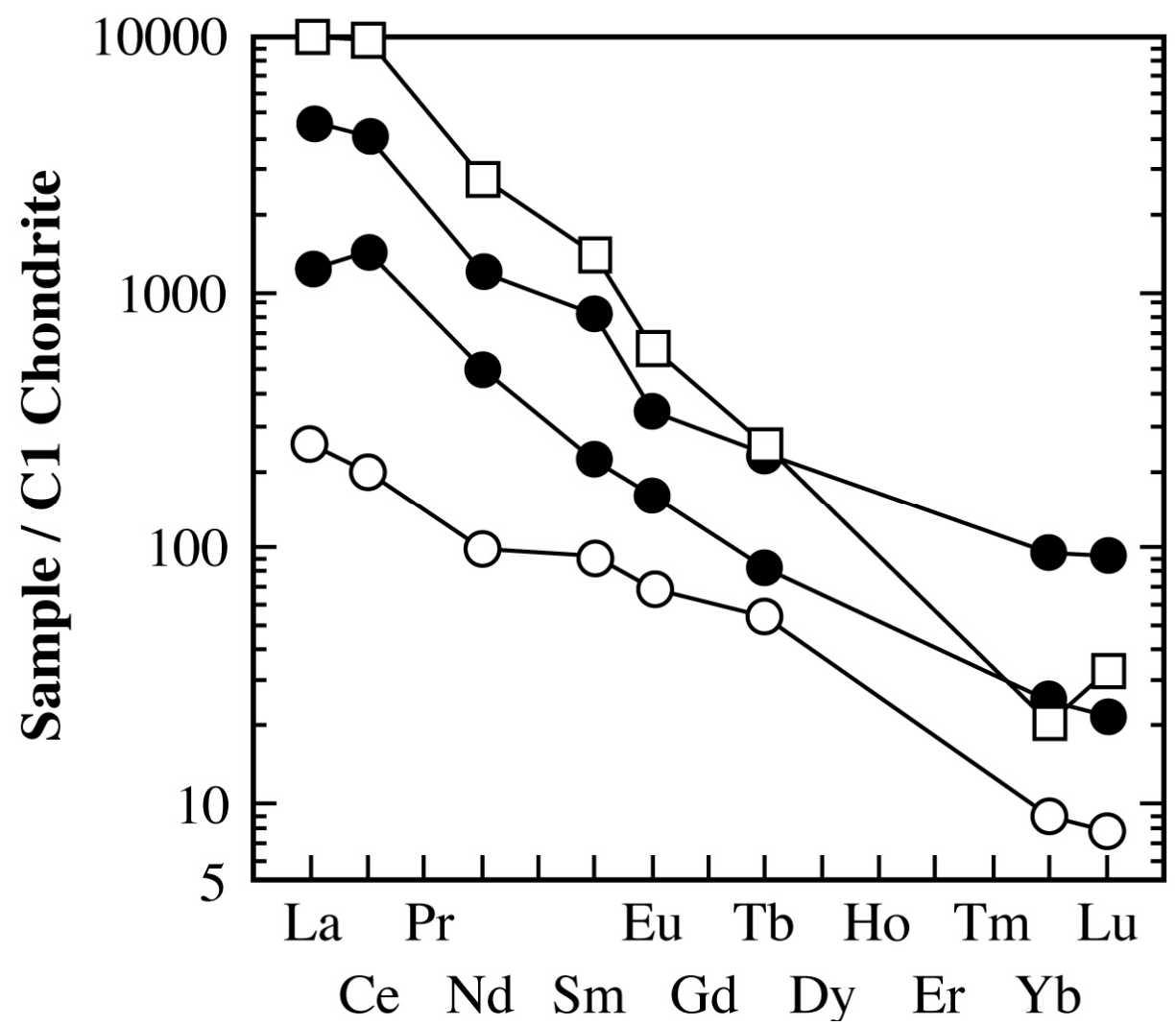

Fig. 8. Chondrite normalized REE distribution patterns of Amba Dongar sövites and alvikites; Open circle - Phase I alvikite, Open square -- Phase II alvikite, Filled circle - 2 phases of sövites (coarse and fine grained).

\section{6. $C$ and $O$ isotopes}

Stable isotopes of carbon and oxygen have proved useful in differentiating primary igneous carbonatites from marine carbonates. Relative to the PDB standard, mantle derived carbon has a $\delta^{13} \mathrm{C}$ range of -7 to $-5 \%$, and relative to the SMOW standard, mantle oxygen has a $\delta^{18} \mathrm{O}$ range of +5 to $+8 \%$ [10] [11]. However, various types of carbonatites (e.g., calcitic, dolomitic, ankeritic) may have evolved from a set of source values typical of the above range, and have undergone fractional crystallization and subsequent magmatic hydrothermal or meteoric alteration in diverse environments subsequent to their 
emplacement. Therefore, it is customary to divide carbonatites broadly into two categories, primary and secondary. In the former variety, variations in both the isotope ratios (viz., $\delta^{13} \mathrm{C}$ and $\delta^{18} \mathrm{O}$ ) occur mainly due to fractional crystallization; the $\delta^{13} \mathrm{C}$ values range from -9 to $1 \%$, while $\delta^{18} \mathrm{O}$ ranges from +5 to $+15 \%$ [12] [10]. In the second (altered) variety, the $\delta^{18} \mathrm{O}$ values can increase up to $+30 \%$, close to that of marine carbonates [13].

The data obtained on $\mathrm{C}$ and $\mathrm{O}$ isotopes of sövite, alvikites (I \& II) supports the observation that calciocarbonatite magma at the Amba Dongar carbonatites complex, is mantle derived as majority of sövite samples and a few alvikites have retained the primary mantle signature. Accordingly, it is seen that the majority of sövite samples and few alvikite I and II plot in the field of mantle derived primary carbonatites in Fig. 9 [14]. Two samples of alvikite I fall within the mantle box while, remaining plot close to the box. Majority of alvikite II plot outside the box and this trend can be explained by process of fractionation. The sövite samples which lie farther away from the mantle box are mostly medium to fine grained sövites. The arrow shows the relation between phenocryst in sövite (star) and the

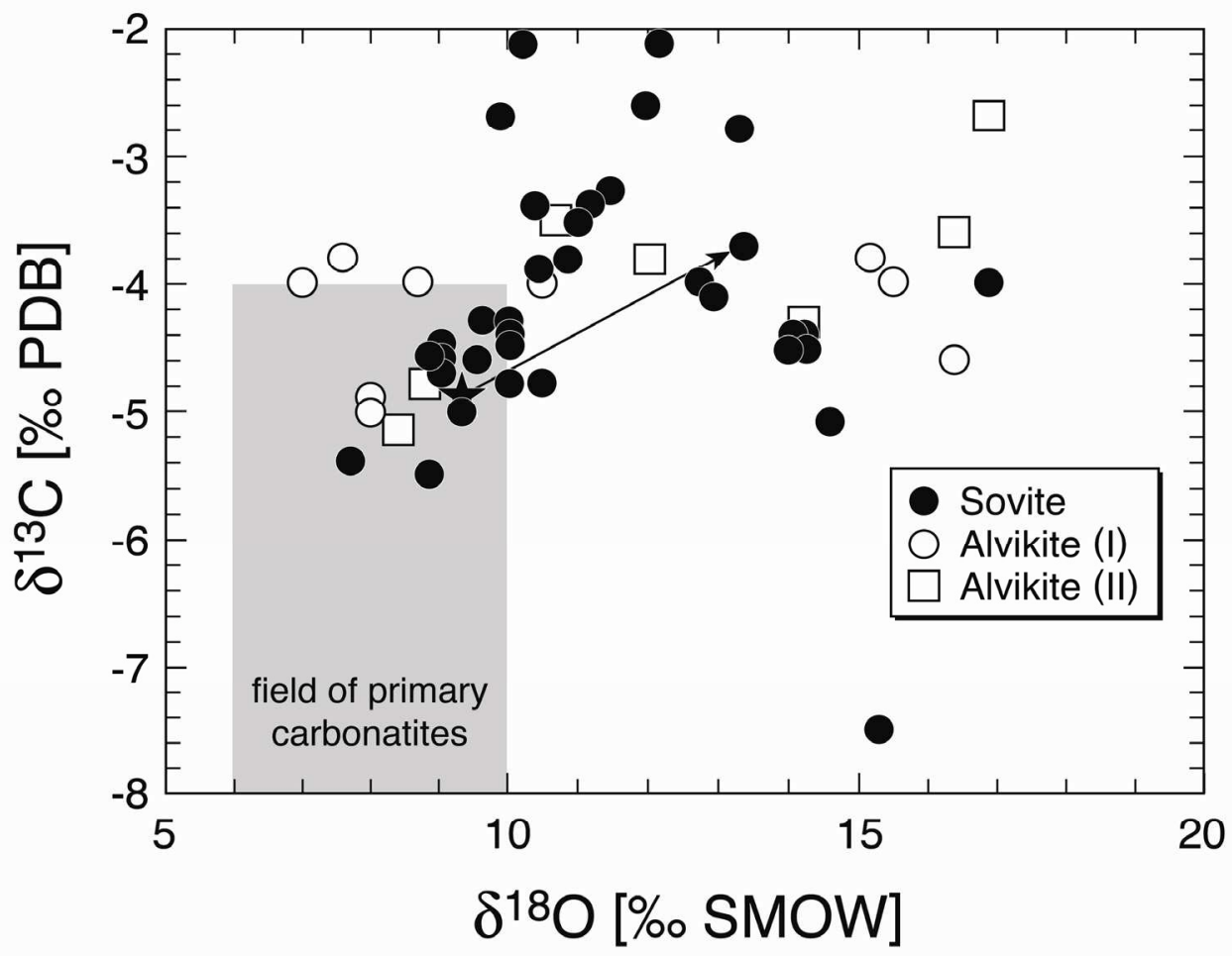

Fig. 9. C and O compositions of sövite, alvikite I and alvikite II of Amba Dongar complex. Open circle - Phase I alvikite, Open square -- Phase II alvikite, Filled circle - 2 phases of sövites (coarse and fine grained). 
groundmass sövite. Coarse-grained sövite, in general, has lower $\delta^{13} \mathrm{C}$ and $\delta^{18} \mathrm{O}$ values compared to fine grained ones, indicating that the fractional crystallization of the carbonatite magma initiated with the crystallization of coarse-grained sövite. As fractionation proceeded, the magma continuously became enriched in water (i.e., the $\mathrm{CO}_{2} / \mathrm{H}_{2} \mathrm{O}$ ratio decreased), at which time crystallization of fine-grained sövites started, thus explaining their higher $\delta^{13} \mathrm{C}$ and $\delta^{18} \mathrm{O}$ values.

It thus can be concluded that the primary carbonatites of Amba Dongar are interpreted to have evolved from a carbonatite parent magma of $\delta^{18} \mathrm{O}=8 \%$ ond $\delta^{13} \mathrm{C}=-5.3 \%$. The initial molar ratio of $\mathrm{H}_{2} \mathrm{O}$ to $\mathrm{CO}_{2}$ that best explains the trend is $\sim 0.9$, with a crystallization temperature of $\sim 800{ }^{\circ} \mathrm{C}$. The secondary carbonatites in Amba Dongar appear to be altered mainly by a hydrothermal fluid with $\mathrm{H}_{2} \mathrm{O} / \mathrm{CO}_{2}$ ratio between 0.001 and 0.1 at temperatures between 100 and $200^{\circ} \mathrm{C}$. This model also applies to the secondary carbonatites found in carbonatite dikes from Amba Dongar [15].

\section{Discussion}

There has been an ongoing debate for many years about whether calciocarbonatite magmas exist or whether calcitic carbonatites are cumulate rocks derived from the crystallization of dolomitic carbonatite magma. While this may be true in some cases the present study of Amba Dongar dikes argues very strongly for the existence of a calcitic carbonatite magma (calciocarbonatite) magma, although somewhat magnesian in its early stages.

In Amba Dongar field relations between sövite and two phases of alvikites and petrographic observations such as tabular plates of calcite aligned along flowage, porphyritic texture with phenocrysts of calcite provide convincing evidence to assume that these carbonatites are crystallized from CaCO3-rich melt. The surface exposures of different generations of carbonatites are very clear and injection of alvikite II into sövite provides indisputable evidence of their origin that they being younger than the main sövite intrusion. With the help of geochemistry of major, trace and rare earth elements the fractionation of calciocarbonatite magma from sövite to two generations alvikite is well documented in the earlier section.

Early experimental studies of Wyllie and Tuttle [16] showed that calcite can crystallize as a liquidus phase at a temperature around $650^{\circ} \mathrm{C}$ at $0.1 \mathrm{GPa}$ pressure.

According to Gittins [17] and Bailey [18] carbonatites can be precipitated from primary calciocarbonatite magma. Bailey listed 8 examples effusive calciocarbonatite [18], (Table 2, p. 6) and majority of them erupted from mantle as primary melt. Mariano and Roedder [19] studied products of Kerimasi carbonatite volcano and concluded that calcite was a primary phase in some flows. It is worth mentioning here that in Amba Dongar too an extrusive phase of calciocarbonatite magma occurs in the form of well bedded tuff and $\mathrm{C}$ and $\mathrm{O}$ isotopes of an unaltered tuff plots in field of mantle derived primary carbonatites [20]. Jago and Gittins [21] and Gittins and Jago [22] suggest, from experimental evidence, that a small amount of fluorine in carbonatite magma can reduce the temperature of crystallization of calcite which allows crystallization of calcite at atmospheric pressure 
and conclude that the most of the calcite in extrusive carbonatite is primary magmatic. Dalton and Wood [23] demonstrated experimentally the formation of primary calciocarbonatite magma at low pressure. This is further supported by experimental results of Wyllie and Lee [24]. Additional evidence of existence of primary calciocarbonatite comes from occurrence of globules of calcite in mantle xenoliths which has been considered as evidence for the formation of immiscible $\mathrm{CaCO}_{3}$-rich melts in the mantle [25].

It thus appears that calciocarbonatite magma was the primary magma in Amba Dongar and during its evolution differentiated to alvikite I and II. That such calciocarbonatite magma was initially more magnesian is evident from the presence of phlogopite-sövite and periclase bearing sövite [4].

\section{Acknowledgements}

I am grateful to John Gittins for discussions, comments and suggestions on the manuscript. I thank: R. Ramesh of PRL, Ahmedabad for discussions on stable isotope data, Mrs Schegel formerly at Mineralogisches-petrographisches Institute, Freiburg, Germany for technical assistance. Dr. P.B. Pawaskar, formerly at BARC, Trombay, Mumbai for the REE analystical work. Part of the analytical work was done during the tenure of an Alexander von Humboldt fellowship in 1980 for which I thank the AvH Foundation, Germany. For the stable isotope determination I thank Mr. Georg Josten and Hedi Oberhansli for help during the laboratory work and Professor Schidlowski for guidance and discussions. I also gratefully acknowledge receipt of a Max-Planck Fellowship for conducting this investigation.

\section{References}

[1] Ray, J.S., Kanchan Pande and Venkatesan, T.R. (2000) Emplacement of Amba Dongar carbonatite alkalic complex at Cretaceous/Tertiary boundary: Evidence from ${ }^{40} \mathrm{Ar} /{ }^{39} \mathrm{Ar}$ chronology. Proc. Ind. Aca. Sci. (Earth Planet.Sci) 109: 39- 47.

[2] Viladkar, S.G. (1986) Fenitization at the Amba Dongar carbonatite alkalic complex. Proce. Sympo. NEMIRAM, Czechoslovakia: pp170-189

[3] Viladkar, S.G. (1996) Geology of the Carbonatite-Alkalic Diatreme of Amba Dongar Gujarat. GMDC Sci. and Research Centre, Ahmedabad : pp1-74

[4] Viladkar, S.G. and Wimmenauer, W. (1992). Geochemical and Petrological studies on the Amba Dongar carbonatites (Gujarat, India). Chem. Erde. 52:277-291.

[5] Viladkar, S.G., Ramesh, R., Avasia, R.K. and Pawaskar, P.B. (2005). Extrusive phase of Carbonatite-Alkalic activity in Amba Dongar complex, Chhota Udaipur, Gujarat. Geol. Soc. India. 66: 273-276.

[6] Viladkar, S.G., (1981): The carbonatites of Amba Dongar, Gujarat, India. Bull. Geol. Soc. Finland. 53: 17-28

[7] Viladkar, S. G. (2000) Phlogopite as indicator of magmatic differentiation in the Amba Dongar carbonatite, Gujarat, India. N. Jb.Miner. Mh. 7: 302-314. 
[8] McCrea, J. M. (1950) The isotopic chemistry of carbonates and a palaeotemperature scale. J. Chem. Phys. 18: 849-857

[9] Craig, H., (1957) Isotopic standards for carbon and oxygen and correction factors for mass spectrometric analysis of carbon dioxide. Geochim. Cosmochim. Acta. 12: 133149.

[10] Deines, P. (1989) Stable isotope variations in carbonatites, In: Carbonatites: genesis and evolution editor K. Bell. Unwin Hyman, London pp301-359.

[11] Keller, J. and Hoefs, J. (1995) Stable isotope characteristics of recent natrocarbonatite from Oldoinyo Lengai, In: Carbonatite Volcanism: Oldoino Lengai and the Petrogenesis of Natrocarbonatites, Editors K. Bell and J. Keller, IAVCE I, Proc. Volcanol. 4: pp113-123.

[12] Plyusnin, G. S., Samoylov, V.S., and Gol'shev, S.I.(1980) The $\delta^{13} \mathrm{C}$, $\delta^{18} \mathrm{O}$ isotope pair method and temperature facies of carbonatites, Doklady Akademi Nank USSR, Seriya Geologiya. 254:1241-1245.

[13] Ray, J. S. and Ramesh, R., 1999. Evolution of carbonatite complexes of Deccan Flood Basalt province: stable carbon and oxygen isotopic constraints J. Geophys. Res.B12, 104, 29471-29483.

[14] Taylor, H.P. Jr. Frenchen, J. and E.T. Degens (1967) Oxygen and carbon isotope studies of carbonatites from the Laacher See district, West Germany and the Alnö district, Sweden. Geochim Cosmochim Acta. 31: 407-430

[15] Viladkar, S.G. and R. Ramesh Stable Isotope geochemistry of some Indian carbonatites: Implications for post-emplacement hydrothermal alteration processes (in preparation)

[16] Wyllie, P.J. and O.F. Tuttle (1960a) The system $\mathrm{CaO}-\mathrm{CO}_{2}-\mathrm{H}_{2} \mathrm{O}$ and the origin of Carbonatites. J. Petrol. 1: 1-96.

[17] Gittins, J. (1989) The origin and evolution of carbonatite magmas. In Carbonatites: Genesis and evolution Editor K. Bell. London, Unwin Hyman : pp580-600.

[18] Bailey, D.K. (1993) Carbonatite magmas. J. Geol. Soc. 150 : 637-651.

[19] Mariano, A. N. and P.L. Roedder (1977) Kermasi: a neglected carbonatite volcano. J. Geol, 91: 449-455.

[20] Viladkar, S.G., Ramesh, R., Avasia, R.K. and Pawaskar, P.B. (2005). Extrusive phase of Carbonatite-Alkalic activity in Amba Dongar complex, Chhota Udaipur, Gujarat. Geol. Soc. India. 66: 273-276.

[21] Jago, B.C. and Gittins, I. (1991) The role of fluorine in carbonatite magma evolution. Nature. 349: 56-58.

[22] Gittins. J and B.C. Jago (1991) Extrusive carbonatites: their origins reappraised in the light of new experimental data. Geol Mag. 128, 4: 301-305.

[23] Dalton J.A. and Wood B.J. (1993) The compositions of primary carbonate melts and their evolution through wall rock reactions in the mantle. Earth \& Plan. Sci Lett 119: 511-525.

[24] Wyllie, P. J. and Lee, W.J. (1998) Model system controls on conditions for formation of magnesiocarbonatite and calciocarbonatite magmas from the mantle. J. petrol. 39 : 1885-1893. 
[25] Kogarko, L.N., C.N.B. Henderson and H. Pacheko (1995) Primary ca-rich carbonatite Magma and carbonate-silicate-sulphide liquid immiscibility in the upper mantle. Contr. Miner. Petrol. 121: 267-274. 


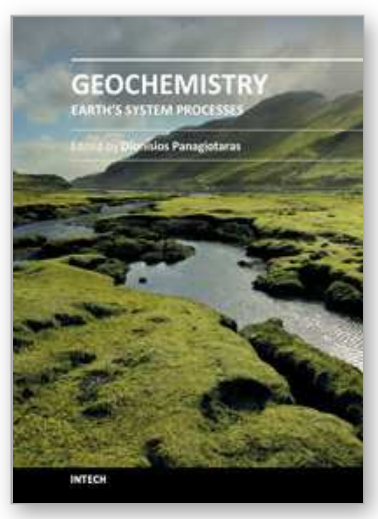

\author{
Geochemistry - Earth's System Processes \\ Edited by Dr. Dionisios Panagiotaras
}

ISBN 978-953-51-0586-2

Hard cover, 500 pages

Publisher InTech

Published online 02, May, 2012

Published in print edition May, 2012

This book brings together the knowledge from a variety of topics within the field of geochemistry. The audience for this book consists of a multitude of scientists such as physicists, geologists, technologists, petroleum engineers, volcanologists, geochemists and government agencies. The topics represented facilitate as establishing a starting point for new ideas and further contributions. An effective management of geological and environmental issues requires the understanding of recent research in minerals, soil, ores, rocks, water, sediments. The use of geostatistical and geochemical methods relies heavily on the extraction of this book. The research presented was carried out by experts and is therefore highly recommended to scientists, underand post-graduate students who want to gain knowledge about the recent developments in geochemistry and benefit from an enhanced understanding of the dynamics of the earth's system processes.

\title{
How to reference
}

In order to correctly reference this scholarly work, feel free to copy and paste the following:

S. G. Viladkar (2012). Evolution of Calciocarbonatite Magma: Evidence from the Sövite and Alvikite Association in the Amba Dongar Complex, India, Geochemistry - Earth's System Processes, Dr. Dionisios Panagiotaras (Ed.), ISBN: 978-953-51-0586-2, InTech, Available from: http://www.intechopen.com/books/geochemistryearth-s-system-processes/evolution-of-calciocarbonatite-magma-evidence-from-the-sovite-and-alvikiteassociation-in-the-amba-d

\section{INTECH}

open science | open minds

\section{InTech Europe}

University Campus STeP Ri

Slavka Krautzeka 83/A

51000 Rijeka, Croatia

Phone: +385 (51) 770447

Fax: +385 (51) 686166

www.intechopen.com

\section{InTech China}

Unit 405, Office Block, Hotel Equatorial Shanghai

No.65, Yan An Road (West), Shanghai, 200040, China

中国上海市延安西路65号上海国际贵都大饭店办公楼 405 单元

Phone: +86-21-62489820

Fax: $+86-21-62489821$ 
(C) 2012 The Author(s). Licensee IntechOpen. This is an open access article distributed under the terms of the Creative Commons Attribution 3.0 License, which permits unrestricted use, distribution, and reproduction in any medium, provided the original work is properly cited. 